\title{
In vitro antioxidant activity of Psidium guajava Linn. by using ethanolic extract fraction of leaves and bark.
}

\author{
Subba Rao Ch*, Arun Kumar S, Javvad Ali, Priyadarshini P, Hinduja M, Keerthi R, Nivedita L, Priyanka D \\ Department of Pharmacognosy, Vaageswari College of Pharmacy, Karimnagar, JNTUH, India
}

\begin{abstract}
Guava is most popular and commonly available plant all over the India. This study is about the evaluation of in vitro antioxidant activity of Psidium guajava Linn. The leaves and bark of the Psidium guajava Linn. are used for study of the antioxidant activity. Ethanolic extract of these leaves and bark is used for this evaluation study. Nitric oxide and DPPH methods are used to evaluate free radical scavenging activity.
\end{abstract}

Keywords: Guava, Anti-oxidant activity, Ethanolic extract, Nitric oxide, DPPH method.

Accepted on March 29, 2018

\section{Introduction}

Modernisation has made many changes and modifications in the lifestyle of society, resulting in drastic increase of several disorders and diseases. Various studies have reported that consumption of good diet (vegetables, fruits) is necessary in reducing the riskfactor of many dieases [1-3].

Plants have been used for medicinal purpose from ancient times. Among many countries, India is one of the richest ancient repositories of medicinal plants. From the time of immortal Medicinal plants are used in treatment of many diseases, they are considered safe and effective. These remedies are in syn. with nature, which is biggest advantage.

Traditional medicines have deep roots in culture of ancient heritage. Ancient scholars believed that herbs are only solution for many health related problems.

The advances in various scientific field have proved that plants contain active chemical constituents.

The constituents of guava include vitamins, tannins, phenolic compounds, flavonoids, essential oils, sesquiterpene alcohols and tri terpenoid acids. Some of the therapeutic activities of Guava leaf extract are analgesic, anti-inflammatory, antimicrobial, hepatoprotective and anti-oxidant, due to the presence of phenolic group.

\section{Plant Profile}

Botanical name: Psidium guajava Linn.

Family: Myrtaceae.

Common names: Guava, common guava, yellow guava, apple guava.

Parts used: Fruits, leaf, flower, root and bark.

\section{Materials and Methods}

\section{Collection and authentication}

Leaves and bark were used for the ethonolic extraction to identify the antioxidant activity from the plant which was collected during the month of july 2010 from vaageswari college of pharmacy, Karimnagar, Telangana under the guidance and authentication of Dr. Jayaraman, director of Plant aatomy centre (PARC), Tambaram, Chennai. A voucher specimen No. PARC /2010/594 has been deposited for further reference.

\section{Extraction process}

Shade dry and coarsley powder the Leaves and Bark of Psidium guajava Linn.. Concentrate around 300 gm of powdered medication with ethanol by cold maceration method, after 72 hrs of maceration filtration was followed [4,5]. After entire extraction, the concentrate was focused by refining off the dissolvable and afterward utilizing vaccum flash evaporator. The concentrate was dissipated to dryness under diminished weight. Using high polarity solvents like chloroform, petroleum ether, ethanol the yield was extracted. After which the fractions where evaporated. Its colour and consistencies were also observed Under vaccum. Percentage yield was calculated on air dried basis [6,7].

Phytochemical screening: the concentrate ethonolic extract was subjected to qualitative qualitative phytochemical test for identification of constituents.

\section{Pharmacological Studies}

\section{In vitro antioxidant studies}

Oxidation is one of the important biological processes for the production of energy in living organism. Living organisms uses oxidation for the production of energy to fuel biological processes [8-10]. A variety of physiological and biochemical lesions increasingly deteriorate degenerative diseases such as aging, cancer and coronary artery disease due to free radicals Despite of anti-oxidant defence and other defence mechanism in human these systems are insufficient to prevent the damage entirely. Antioxidants are the substances that can inhibit or restrict oxidative cellular oxidizable substrates.

\section{DPPH radical scavenging activity}

The free radical scavenging activity is measured in the terms of hydrogen donating or radical scavenging ability, using the stable radical, DPPH. 
Citation: Subba Rao Ch, Arun Kumar S, Jawed F Ali, et al. In vitro antioxidant activity of Psidium guajava Linn. by using ethanolic extract fraction of leaves and bark. Adv Cell Sci Tissue Cult. 2018;2(1):12-15

Preparation of DPPH solution:

About $0.1 \mathrm{mM}$ DPPH crystalline solid was taken in test tube, slowly dissolve the crystalline using organic solvent like methanol to form a solution.

The ethanolic extraction, standard (vitamin c) and control (without the test compound but with an equivalent amount of methanol) with a different concentration $(50,100,200,400,800,1000 \mu \mathrm{g} / \mathrm{ml})$ of about $3 \mathrm{ml}$ each were taken in test tube $[11,12]$. To this ethanolic extract add $1 \mathrm{ml}$ of DPPH solution slowly. Shake the concentrate solution and enable it to remain at room temperature for about 30 min and the absorbance was measured at $517 \mathrm{~nm}$ using a spectrophotometer. The IC50 value (half of inhibitory focus in $\mu \mathrm{g} / \mathrm{ml}$ ) was compared with standard solution i.e., vitamin C. Free radical scavenging activity is identified by the decrease in the absorbance of the reaction mixture [13-15].

The percentage inhibition of DPPH radical was calculated using the formula,

$$
\text { Percentage inhibition }(\%)=\frac{(\text { Abs of control }- \text { Abs of test })}{\text { Abs of control }} \times 100
$$

\section{Nitric oxide scavenging activity}

Nitric oxide was generated by sodium nitroprusside and measured by Griess reaction. Sodium nitroprusside $(5 \mathrm{mM})$ in standard phosphate buffer saline solution $(0.025 \mathrm{M}, \mathrm{pH}$ : 7.4) was incubated with different concentrations of ethanolic extact $(50,100,200,400,800,1000 \mu \mathrm{g} / \mathrm{ml})$, Vitamin $\mathrm{C}$ as reference standard $(50,100,200,400,800,1000 \mu \mathrm{g} / \mathrm{ml})$ and dissolved in phosphate buffer saline $(0.025 \mathrm{M}, \mathrm{pH}: 7.4)$ and the tubes were incubated at $25^{\circ} \mathrm{C}$ for $5 \mathrm{hr}$ [16-19]. Control experiments without the test compounds but equivalent amounts of buffer were conducted in an identical manner. After 5 hours, $0.5 \mathrm{ml}$ of incubation solution is removed and diluted with $0.5 \mathrm{ml}$ of Griess reagent (1\% sulphanilamide, $2 \%$ O-phosphoric acid and $0.1 \%$ naphthyl ethylene diamine dihydrochloride). The absorbance of the chromophore formed during diazotization of nitrite with sulphanilamide and its subsequent coupling with naphthyl ethylene diamine was read at $546 \mathrm{~nm}$. All the determinations were performed in 6 replicates. Percentage inhibition of nitric oxide radical was calculated by using the formula:

Percentage inhibition $(\%)=\frac{(\text { Abs of control }- \text { Abs of test })}{\text { Abs of control }} \times 100$

\section{Results}

\section{Phytochemical screening}

A positive remark for saponins, Flavonoids, Phenplic compound and Steroids were identified using phytochemical test in the Psidium guajava leaf (Tables 1-5, Figures 1 and 2).

\section{Discussion}

Psidium guajava Linn. is classified under family: Myrtaceae. It is a widely spread throughout the India and possess some therapeutic activities like antiseptic, antihelmintic, wound healing and in inflammatory conditions [20,21]. Some of the studies suggest that it contain of high amount of of ethanolic
Table 1. Phytochemical screening of Psidium guajava leaf.

\begin{tabular}{|c|c|c|c|c|}
\hline Chemical Test & $\begin{array}{c}\text { Petroleum } \\
\text { ether } \\
\text { Fraction }\end{array}$ & $\begin{array}{c}\text { Chloroform } \\
\text { Fraction }\end{array}$ & $\begin{array}{c}\text { Aqueous } \\
\text { Fraction }\end{array}$ & $\begin{array}{c}\text { Ethanol } \\
\text { Fraction }\end{array}$ \\
\hline Alkaloids & - & - & - & - \\
\hline Carbohydrates & - & - & - & - \\
\hline Glycosides & - & - & - & - \\
\hline Flavonoid & - & - & + & + \\
\hline Tannin & - & - & + & + \\
\hline Terpenoids & - & + & - & + \\
\hline Oil and fats & - & - & - & - \\
\hline Steroids & + & + & - & + \\
\hline
\end{tabular}

(-) indicates absent

$(+)$ indicates present.

Table 2. Phytochemical screening of Psidium guajava bark.

\begin{tabular}{|c|c|c|c|c|}
\hline Chemical Test & $\begin{array}{c}\text { Petroleum ether } \\
\text { fraction }\end{array}$ & $\begin{array}{c}\text { Chloroform } \\
\text { Fraction }\end{array}$ & $\begin{array}{c}\text { Aqueous } \\
\text { fraction }\end{array}$ & $\begin{array}{c}\text { Ethanol } \\
\text { Fraction }\end{array}$ \\
\hline Alkaloids & - & - & - & - \\
\hline Carbohydrates & - & - & - & - \\
\hline Glycosides & - & - & - & - \\
\hline Proteins & - & - & - & - \\
\hline Amino acids & - & - & - & - \\
\hline Saponins & + & - & - & + \\
\hline Flavonoids & - & - & + & + \\
\hline Tannin & - & - & + & + \\
\hline Terpenoids & - & + & - & - \\
\hline Oil and fats & - & - & - & - \\
\hline Steroids & + & + & - & + \\
\hline
\end{tabular}

$(+)$ indicates present

$(-)$ indicates absent.

Table 3. Phytochemical Screening of Psidium guajava Leaf and Bark (Dried powder).

\begin{tabular}{|c|c|c|}
\hline Chemical Test & Dried powder (Leaf) & Dried powder (Bark) \\
\hline Alkaloids & - & - \\
\hline Protein & - & - \\
\hline Amino acids & - & - \\
\hline Saponins & + & - \\
\hline Flavonoids & + & + \\
\hline Tannin & + & + \\
\hline Terpenoids & - & - \\
\hline Oil and fats & - & - \\
\hline
\end{tabular}

Table 4. Free radical scavenging activity of psidium guajava bark and leaf of ethanolic extract by DPPH method.

\begin{tabular}{|c|c|c|c|c|}
\hline \multirow[b]{2}{*}{ S.NO } & \multirow[b]{2}{*}{$\begin{array}{l}\text { Concentration } \\
(\mu \mathrm{g} / \mathrm{ml})\end{array}$} & \multicolumn{3}{|c|}{ \% INHIBITION } \\
\hline & & $\begin{array}{l}\text { STANDARD } \\
\text { (Vitamin-C) }\end{array}$ & LEE & BEE \\
\hline 1 & 50 & $56.438 \pm 0.7557$ & $14.94 \pm 0.2474^{* *}$ & $13.794 \pm 0.2322^{* *}$ \\
\hline 2 & 100 & $65.55 \pm 0.679$ & $20.164 \pm 0.4004^{* *}$ & $19.338 \pm 0.3371^{* *}$ \\
\hline 3 & 200 & $70.256 \pm 0.8019$ & $32.316 \pm 0.6935^{\star *}$ & $37.298 \pm 0.5346^{\star *}$ \\
\hline 4 & 400 & $73.378 \pm 0.7377$ & $42.238 \pm 0.7685^{\star *}$ & $44.128 \pm 0.6945^{\star *}$ \\
\hline 5 & 800 & $76.40 \pm 0.7823$ & $48.956 \pm 0.5805^{\star *}$ & $50.186 \pm 0.4745^{\star *}$ \\
\hline 6 & 1000 & $82.36 \pm 0.7078$ & $59.706 \pm 0.4995^{\star \star}$ & $59.054 \pm 0.6795^{\star *}$ \\
\hline 7 & $\mathrm{IC}_{50}$ & $540(\mu \mathrm{g} / \mathrm{ml})$ & $630(\mu \mathrm{g} / \mathrm{ml})$ & $590(\mu \mathrm{g} / \mathrm{ml})$ \\
\hline
\end{tabular}

The values are expressed as Mean \pm SEM, $n=6$ in each group. If ${ }^{*} P<0.05,{ }^{*} P<0.01$ and ${ }^{* *} \mathrm{P}<0.001$ vs. control.

extract substances. Hence the present research emphasis on isolation of ethanolic extract and its evaluation for antioxidant activity. The young leaves juice is used to treat the imbalances of the digestive function. It is also said to be a remedy for the toothache. 


\section{Phytochemical study}

Various phytochemical screening were carried out for the identification of the various phytoconstituents present in the ethanolic extract fractions

\section{In vitro antioxidant study}

Mammalian cells produce nitric oxide in form of free radicals, which is involved in the regulation of various physiological

Table 5. Free radical scavenging activity of Psidium guajava bark and leaf of ethanolic extract by Nitric oxide method.

\begin{tabular}{|c|c|c|c|c|}
\hline \multirow{2}{*}{ S.NO } & \multirow{2}{*}{$\begin{array}{c}\text { Concentration } \\
(\mu \mathrm{g} / \mathrm{ml})\end{array}$} & $\begin{array}{c}\text { Standard } \\
(\text { Vitamin-C) }\end{array}$ & LEE & BEE \\
\hline 1 & $50(\mu \mathrm{g} / \mathrm{ml})$ & $8.30 \pm 0.45$ & $38.496 \pm 0.0534^{* *}$ & $41.83 \pm 0.0365^{\star *}$ \\
\hline 2 & $100(\mu \mathrm{g} / \mathrm{ml})$ & $16.66 \pm 0.90$ & $41.748 \pm 0.1393^{\star *}$ & $42.72 \pm 0.0634^{\star *}$ \\
\hline 3 & $200(\mu \mathrm{g} / \mathrm{ml})$ & $27.77 \pm 1.08$ & $45.18 \pm 0.024^{\star *}$ & $45.34 \pm 0.033^{* *}$ \\
\hline 4 & $400(\mu \mathrm{g} / \mathrm{ml})$ & $52.77 \pm 0.60$ & $46.178 \pm 0.030^{* *}$ & $46.196 \pm 0.025^{\star *}$ \\
\hline 5 & $800(\mu \mathrm{g} / \mathrm{ml})$ & $61.11 \pm 0.51$ & $46.472 \pm 0.081^{* *}$ & $46.662 \pm 0.0316^{\star *}$ \\
\hline 6 & $1000(\mu \mathrm{g} / \mathrm{ml})$ & $65.88 \pm 0.84$ & $47.294 \pm 0.048^{* *}$ & $47.494 \pm 0.0285^{\star *}$ \\
\hline 7 & $1 C_{50}$ & $380(\mu \mathrm{g} / \mathrm{ml})$ & $560(\mu \mathrm{g} / \mathrm{ml})$ & $540(\mu \mathrm{g} / \mathrm{ml})$ \\
\hline
\end{tabular}

The values are expressed as Mean \pm SEM, $n=6$ in each group. If ${ }^{*} \mathrm{P}<0.05,{ }^{*} \mathrm{P}<0.01$ and ${ }^{* * *} \mathrm{P}<0.001$ vs. control. reactions [22]. Under aerobic conditions nitric oxide is very unstable species. Nitric oxide when undergoes metabolism, produce nitrate and nitrite as an end product through intermediates. It is estimated by using the Griess reagent and in presence of test compound which was the scavenger.

In the present research, sodium nitroprusside in standard phosphate saline buffer at $25^{\circ} \mathrm{C}$ was incubated to produce nitrite. It was estimated that due to the presence of ethanol, free radical scavenging property can be produced using the above method.

$D P P H$ assay is considered as a valid method to evaluate scavenging activity of antioxidants, since the radical compound is very stable and do not have to generate as in other radical assays. DPPH radicals react with suitable reducing agents and then electrons become paired off and the solutions loses colour stoichiometrically with the number of electrons taken up. such reactivity has been widely used to test the ability of plant extract to act as free radical scavengers. DPPH assay of ethanolic extract showed a dose dependent increase in the percentage of inhibition of free radicals $[23,24]$. The ethanolic extract fraction was found to show a good antioxidant potential.

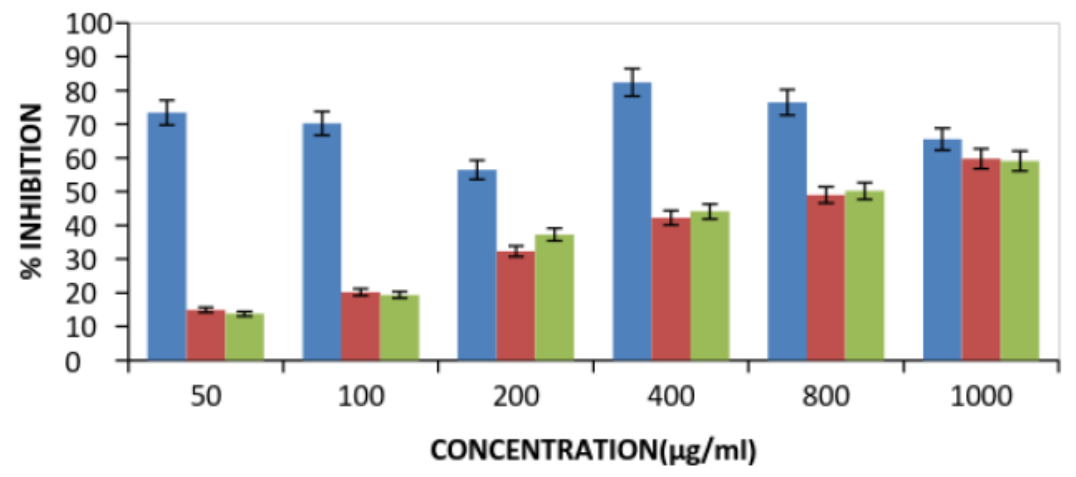

$\begin{array}{lll}\text { - } & \text { LEE } & \text { - Leaf ethanolic extract } \\ \text { - } & \text {-BEE } & \text { - Bark ethanolic extract } \\ \text { - } & \text {-Standard } & \text { - Vitamin-C }\end{array}$

Figure 1: DPPH free radical scavenging activity of STANDARD, LEE and BEE.

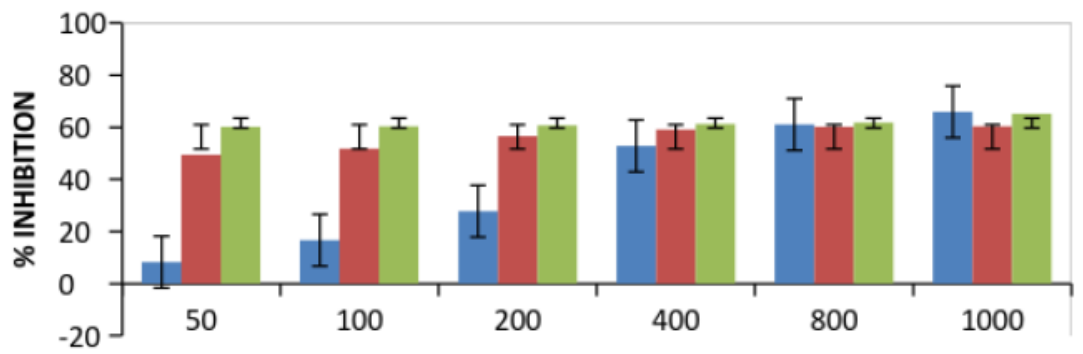

CONCENTRATION $(\mu \mathrm{g} / \mathrm{ml})$

$\begin{array}{llll}\text { - } & \text {-LEE } & - & \text { Leaf ethanolic extract } \\ \text { - } & \text {-BEE } & - & \text { Bark ethanolic extract } \\ \text { - } & \text {-Standard } & - & \text { Vitamin-C }\end{array}$

Figure 2: Nitric oxide scavenging activity of STANDARD (vit-C), LEE and BEE. 


\section{Conclusion}

From this, we can infer that ethanolic extricate from leaves and bark of Psidium guajava Linn. have huge significant antioxidant activity in all In vitro models based on free radical searching property. The antioxidant activity, is most likely due to the presence of ethanolic extract.

\section{References}

1. Ji XD, Pu QL, Garraffo $M$ Characterisation of the compounds present in the essential oil. Journal of Essential Oil Research 1991;3(3):187-9.

2. Adeyemi phytochemical and trypanocidal activity of Ethanolic leaf Extract in rats infected with Trypnosoma brucei. Journal of Medicinal Plants Research 2009;3 420-3.

3. Kumar A, Tandon S, Naquvi AA, et al. Composition of leaf and twigs oil of Psidium guajava. Indian Perfumer 2005;49(1):73-5.

4. Abdelrahim SI, Atragboul AZ, Omer MEA. Screening of Psidium guajava aqueous bark and methanolic extract and antibacterial activity. Fitoterpia 2002;73:713-5.

5. DharaAK, Gebremariam B, Nag chowdary. Neuropharmacological evolution of Psidium gujava fruit. Indian Journal of Pharmaceutical Sciences 1994;4(54):164.

6. Chaterjee A, Pakrashi SC. The treatise on Indian Medicinal Plants.

7. Rattanachaikunsopon P, Phumkhachorn P. Antibacterial activity of flavonoid. Journal of Medical Plants Research 2010;4(5):393-6.

8. Plants' National Institute of Science Communication and Information Resource. New Delhi 2003;4:14-6.

9. Agarwal SS, M Paridavi. Herbal drug Technology Nirli Prakashan Publications 2007.

10. Ashok Kumar K, Lakshman KN, Jayaveera Estimation of Gallic Acid 2010.

11. Quercetin R. Termina lia chebula by HPTLC Jordan. Journal of Pharmaceutical Sciences.
12. Amarawiez R, Traszynska A, Pegg RB. Antioxidative and radical scavenging effect of phenolics from Vicia sativum Fitoherapia 2008;79:121-2.

13. Deguchi Y, Miyazaki K. Anti-hyper glycemic and antihyperlipidimic effects of guava Phytopharm 2010;11:3-26.

14. Lutterodt A, Basheer IRH. Inhibition of microlax-induced experimental diarrhoea with narcotic like extracts of Psidium gujava. Journal of Ethnopharmacology 1992;37(2):151-7.

15. Fu HZ, Luo YM, Li CJ. Isolated Psidials Phytopharm 2010;11:2-31.

16. Abdu F, Rofina R, Yasmin O, et al. The effect of Piper beetle and Psidium gujava extracts. Journal of Oral Sciences 2006;48:71-5.

17. Gandhisan R, Baburaj TA. Anti-inflammatory action of Lannea coromandelica Hrbc membrane stabilization Fitotherapia 199;62:82-3.

18. Roy CK, Kamath JV. The hepato protective activity of Psidium guajava Linn Indian. Journal of Experimental Biology 2006;44:305-11.

19. Wang GZ. Antioxidant and antiproliferative activities of methanolic extracts of Perilla frutescens. Journal of Medicinal Plants Research 2010;4(6):477-83.

20. Fatima S, Jadhav MJ. Studies on brown rot of guava: isolationpathogenicity and control Bioinfolet 2006;3(1):74.

21. Muruganandan S, Srinivasan K, Tandan SK. Antiinflammatory and analgesic activities of guava Journal of Medicinal and Aromatic Plant Sciences 2001;22:56-8.

22. Gupta VK, Misra AK, Gaur RK. Current status of fusarium wilt disease of guava. Journal of Biotechnology 2010;9:17695.

23. Harborne JB. Phytochemical method guide to modern technique of plant analysis. 1998;83.

24. Jimenez A, Rincon M, Pulido R, et al. Guava fruits as a new source of antioxidant dietary fibre. Journal Of Agricultural and Food Chemistry 2001;49:5489-93.

\section{*Correspondence to:}

Subbarao C

Department of Pharmacognosy

Vaageswari College of Pharmacy

India

Tel: 09502588612

E-mail: chamakurii.subbu@gmail.com 